\title{
V 字型表面织构在油润滑条件下的摩擦学性能
}

\author{
吴元博 ${ }^{1}$, 杨学锋 ${ }^{1}$ ，王守仁 ${ }^{1}$, 成健 ${ }^{2}$, 张辉 ${ }^{1}$, 鹿重阳 ${ }^{1}$, 陈海龙 ${ }^{1}$
}

(1.济南大学 机械工程学院, 山东 济南 $250022 ; 2$. 湖北工业大学 机械工程学院, 湖北 武汉 430000)

\begin{abstract}
摘 要: 为了研究 $V$ 字型织构在油润滑条件下的摩擦学性能, 选取加载力和速度为影响因素, 每个因 素选取 6 个水平,通过 MMG-10 多功能摩擦磨损实验机对环形排列的 V 字型织构进行摩擦磨损实验 研究。并利用 Matlab 软件对实验结果进行数据整理和分析, 结果表明摩擦因数与加载力和速度存在 近线性关系, 它们之间的关系可以通过一个函数方程式表示, 并且加载力对摩擦因数的影响能力要大 于速度。实验后试件的 SEM 图像表明了 V 字型织构的主要磨损区为尖端部分。通过 Solidworks 建立 单个 $\mathrm{V}$ 字型织构模型并使用 CFD 划分网格, 导入到 Fluent 中求解。通过压力分布云图以及湍流强度 云图可知, 油膜的稳定性提高是由于油膜流动性增强和油压值波动小导致的, 尖端部分也正是湍流强 度值较大的区域。而油膜稳定性的提高正是 V 字型织构能在加载力增加的情况下降低摩擦因数的 关键。
\end{abstract}

关 键 词: $\mathrm{V}$ 字型织构; 摩擦磨损实验; 流动性 中图分类号:TH117.1

文献标志码: A

近年来, 摩擦学新理论和实验数据表明, 两运动 摩擦副接触表面并不是越光滑摩擦因数越小, 接触 表面的合理织构可以提高其摩擦学性能 ${ }^{[1-5]}$ 。每年 由于各种形式的摩擦磨损造成约 $80 \%$ 的零件损坏 和 $40 \%$ 的能量损耗, 直接导致了高达数千亿的经济 损失 ${ }^{[6-9]}$ 。因此, 寻找一种提高工件表面摩擦学性 能的表面织构成为国内外学者研究的重点。表面织 构是一种通过在金属或者非金属表面加工制备出具 有特定尺寸和分布规律的图案阵列 ${ }^{[10]}$, 提高了其表 面摩擦学性能。凹坑和沟槽是 2 种典型的织构单 元, 异形织构一一如网纹和异形凹坑, 都是在此基础 上衍生出来的。凹坑织构供油能力差, 但可以促进 油膜形成较高的流体动压力 ${ }^{[11-13]}$ 。沟槽织构的供 油能力强, 可以快速带走磨屑。并且在对沟槽织构 的研究中, 发现平行于滑动方向的沟槽有利于表面 的供油行为, 而垂直于运动方向的沟槽更有利于形 成动压力 ${ }^{[14]}$ 。实验证实, 凹坑、网纹和断纹 3 种不 同织构, 在干摩擦下, 凹坑织构的摩擦因数稳定性最
文章编号 : 1000-2758(2019) 02-0401-06

好,断纹次之,网纹最差 ${ }^{[15]}$ 。在超疏水表面减阻方 面,减阻率会随着凹槽槽宽增大而增大, 受凹槽深度 影响不明显,矩形凹槽比 U 形凹槽有更好的减阻效 果 ${ }^{[16]}$ 。通过研究同种织构不同织构密度在不同速 度和加载力条件下对摩擦因数的影响规律, 发现表 面织构可以使摩擦副在低速下进人流体润滑区域, 扩大了流体润滑的区域 ${ }^{[17]}$ 。通过理论分析不同截 面类型的表面织构和表面形状对摩擦副润滑特性的 影响,发现不同截面类型和表面形状对摩擦副的摩 擦因数和承载能力有很大影响, 并且获得了部分特 定工况下的最优织构参数和类型 ${ }^{[18]}$ 。可见, 织构不 同,工况不同,减摩抗磨的作用机理不同,不同织构 在何种工况下起到最佳效果还有待讨论,需要继续 加大针对不同织构的摩擦学特性研究, 更深人地了 解每种织构,有利于根据工况设计相应的最优织构。 $\mathrm{V}$ 型织构作为异形织构的一种, 类似于相互交叉的 沟槽织构。两者不同之处在于它的每个织构单元是 独立的,而不是像交叉沟槽织构一样是相通的。相

收稿日期:2018-05-07 基金项目: 国家自然科学基金(51575234,51872122); 中国博士后科学基金(2017M620286); 山东省 重点研发计划 (2018CXGC0809) 与山东省农机装备研发创新计划( 2018YF012) 及山东省泰山学者特聘专家资助。

作者简介: 吴元博 (1993-), 济南大学硕士研究生, 主要从事摩擦学研究。

通信作者:杨学锋 (1977一), 济南大学教授, 主要从事摩擦学研究。E-mail: me_yangxf@ ujn.edu.cn 
通的织构在提高润滑油流动性、排除磨屑方面要优 于相互独立的织构, 但流动性增强的副作用是承压 能力的减弱。当流动方向为从 $\mathrm{V}$ 型织构开口处流 向尖端处时, 润滑油被 V 型织构不断挤压, 润滑油 压力增加,油膜承压能力提高。

因此本文以 $\mathrm{V}$ 型表面织构为研究对象, 使用 MATLAB 对实验结果进行分析, 结合 Stribeck 曲线, 并通过 Fluent 软件对 V 型织构进行仿真分析, 深人 研究其摩擦学性能。

\section{1 实验结果及分析}

本实验选取载荷和速度 2 个因素, 载荷因素选 取 6 个水平, 速度因素选取 5 个水平, 水平数的增加 可以更清楚地反应出它们与摩擦因数之间的函数关 系。V 字型表面织构使用 Coherent 公司的 Libra-HE 型飞秒激光器进行织构微雕刻, 单个 $\mathrm{V}$ 型织构的开 口夹角为 $45^{\circ}$, 单边长度 $0.8 \mathrm{~mm}$, 单边宽度 $0.15 \mathrm{~mm}$, 加工深度在 $32 \mu \mathrm{m}$ 左右, 均匀分布, 总面积占有率 为 $10 \%$ 。激光加工技术热影响小、刻划精细、加工 清洁。实验载荷分别选取 $50 \mathrm{~N}, 80 \mathrm{~N}, 100 \mathrm{~N}, 150 \mathrm{~N}$, $180 \mathrm{~N}, 200 \mathrm{~N}$, 速度分别选取 $40 \mathrm{r} / \mathrm{min}, 80 \mathrm{r} / \mathrm{min}, 120$ $\mathrm{r} / \mathrm{min}, 160 \mathrm{r} / \mathrm{min}, 200 \mathrm{r} / \mathrm{min}$ 。在 MMG-10 多功能摩 擦磨损实验机上进行实验, 利用特殊设计的带有正 方形凹槽的对磨件保证整个实验过程都在油润滑条 件下进行。加工完成的试件如图 1 所示。

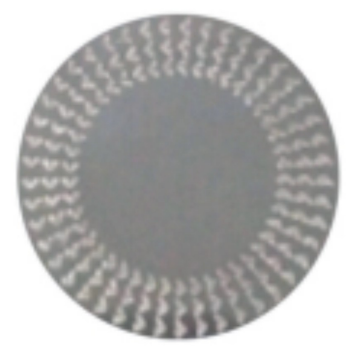

图 1 加工完成后的 $\mathrm{V}$ 字型表面织构示意图

\section{1 实验结果}

摩擦因数取 1600 个数据的平均值。在本实验 中每组摩擦因数皆会取 1800 个值, 只需要后 1600 个并取其平均值。由于表格并不能直观体现整体趋 势和变化规律, 所以使用 MATLAB 软件将数据处理 成三维图像,处理结果如图 2 所示。

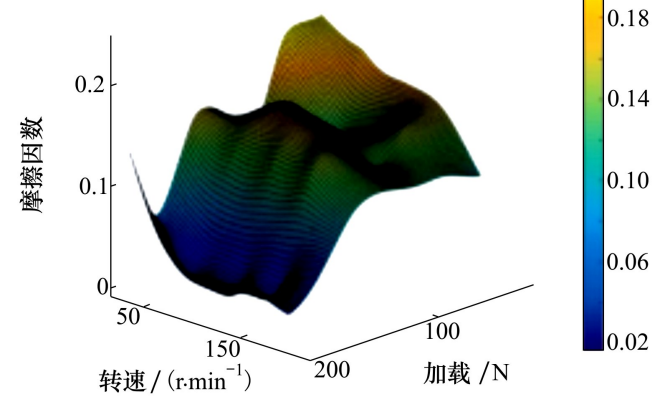

图 2 实验结果三维图

\section{2 结果分析}

根据图 2 可以看出在转速一定时, 随着加载力 的增大一即载荷的增大, 摩擦因数呈现一个减少的 趋势, 利用 MATLAB 自带的拟合工具箱 - curve fitting tool 进行数据拟合。几组数据的拟合结果都 表示, 在速度一定时,摩擦因数和加载力呈类线性关 系, 即通过滤波耦合后符合一定的线性规律。但是 由图 2 可以看出,摩擦因数存在一个固定的“谷”。 无论速度的值为多少, 只要加载力为 $100 \mathrm{~N}$ 时, 摩擦 因数总要比相邻的 2 个加载力 $80 \mathrm{~N}, 150 \mathrm{~N}$ 要小。 虽然存在由误差导致的可能性，但是根据实验结果 来看每个速度值都会遇到这个现象。而且速度越小 时，“谷”越明显，随着速度增大，“谷”逐渐减小。当 加载力过小时, 表面油膜的稳定性较低, 摩擦因数较 大 ; 当加载力增大时, 表面油膜的稳定性提高, 摩擦 因数较小。当加载力在一定值域内时, 油膜稳定性 和加载力会出现一个平衡点, 即加载力刚好使得油 膜稳定性提高。一旦偏离这个点, 加载力会使得油 膜破裂, 从而增大摩擦因数, 这就出现了“峰”。但 是随着加载力的持续增大, 油膜还是向着更稳定的 方向发展,摩擦因数朝着减小的方向发展,这种现象 便不再明显, 只有到达下一个平衡点时才会再次出 现 “谷” 和 “峰” 的波动。在讨论 2 个自变量对 1 个 因变量的影响时,大多使用 MATLAB 的多元线性回 归指令-regeress。带人实验结果后得到方程

$$
y=0.248-0.00076 x_{1}-0.00033 x_{2}
$$

式中, $y$ 表示摩擦因数, $x_{1}$ 为加载力, $x_{2}$ 为速度。相 关系数 $R^{2}$ 的值为 $0.69, F$ 统计值为 30.23 , 与其对应 的 $P$ 值为 $1.28 \times 10^{-7} \mathrm{~N} / \mathrm{m}^{2}$ 。根据以上 MATLAB 的 计算结果可知,加载力和速度对摩擦因数存在函数 关系; 并且由于 $x_{1}$ 的系数大于 $x_{2}$, 说明加载力对摩 擦因数的影响能力要大于速度。 
图 3 和图 4 分别为不同加载力和不同速度时, 通过改变速度和加载力得到的 Stribeck 曲线。 Stribeck 曲线作为探寻摩擦因数 $\mu$ 与速度 $v$ 、黍度 $\eta$ 以及载荷 $p$ 三者关系的曲线, 可以通过曲线变化趋 势区分 3 个变量对摩擦因数的影响能力。

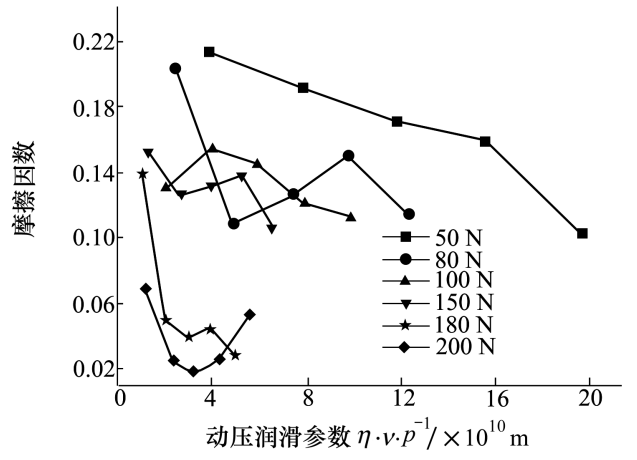

图 3 不同加载力下的 Stribeck 曲线

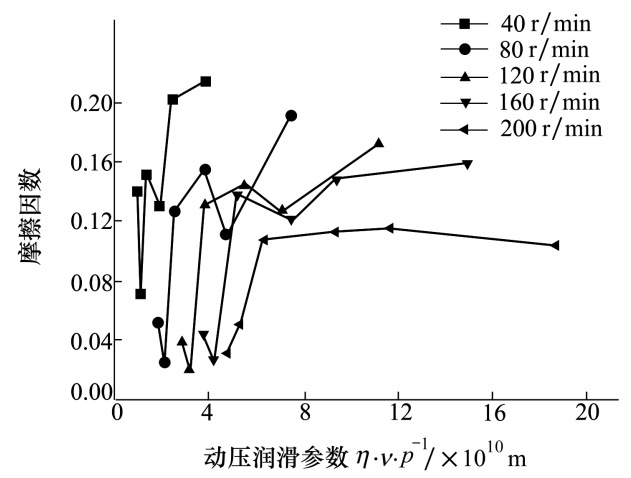

图 4 不同速度下的 Stribeck 曲线

由图 3 中可以看出, 加载力不同时, 摩擦因数变 化规律有着显著差异。在加载力为 $50 \mathrm{~N}$ 时, 摩擦因 数随着速度的增大而减小, 但各个润滑区域区分度 不高, 不能有效地辨别各个润滑区域的范围, 且整体 摩擦因数偏大。随着加载力的增大, 摩擦因数逐渐 降低, 并且各润滑区域界限逐渐分明, 在低速下也可 以进人流体润滑状态。由图 4 可以看出, 速度不同 时,摩擦因数变化规律差异性较小, $40 \mathrm{r} / \mathrm{min}$ 与 80 $\mathrm{r} / \mathrm{min}$ 相比曲线变化规律相似, 并且随着速度的增 加, 相邻曲线的相似度越来越高。在同一速度下, 加 载力增大到一定压力时, 摩擦因数会出现一个急剧 下降的过程,并且速度越大, 这种下降过程越明显。 具体表现为: 当速度越大, 加载力小于突变值时, 摩 擦因数稳定, 变化越突然, 但是变化幅度小; 随着速 度的减小, 摩擦因数波动增加, 但依然保持原有变化 规律。由以上结果, 说明加载力对摩擦因数的影响 比重要大于速度, 这与之前 MATLAB 的分析结果
一致。

\section{3 织构表面的摩擦磨损}

即使 $\mathrm{V}$ 字型织构具有良好的减摩性能,但是依 旧不能避免试件磨损。图 5 为试件表面磨损 SEM 图。由图可以看出在 $\mathrm{V}$ 字型织构的尖端部分存在 凹坑, 且分布在尖端部分的两侧。在远离尖端部分 的区域凹坑较少且不在织构边缘。这是由于尖端部 分润滑油流速快, 流体中的气泡产生气穴现象释放 能量, 从而造成了对织构表面的侵蚀,逐渐形成气蚀 坑。在远离尖端的地方流速降低, 侵蚀效果减弱。

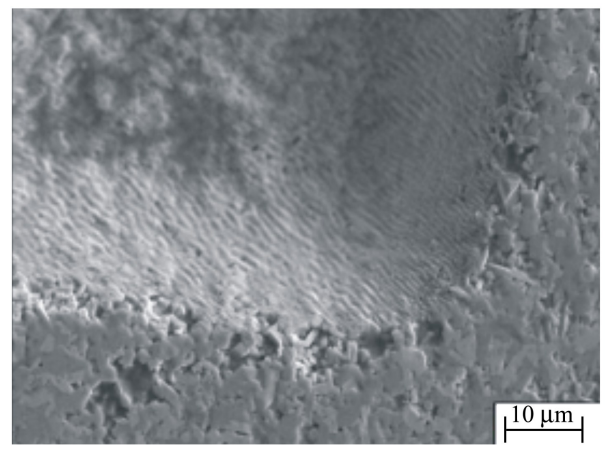

图 $5 \mathrm{~V}$ 字型织构表面磨损的 SEM 图

\section{2 仿真分析}

\section{1 模型建立}

在进行 Fluent 仿真分析之前, 首先要确定研究 对象并建立模型。实验试件的 $\mathrm{V}$ 字型织构呈环形 排列。在 Fluent 进行仿真时如果按照试件建立模 型, 精度可能不够, 而且计算量会非常大。所以, 采 用管中窥豹的方法-通过某一个 $\mathrm{V}$ 字型织构的分析 结果来体现整体的规律。

利用 Solidworks 建立单个 $\mathrm{V}$ 字型织构的模型, 并利用 ICEM CFD 进行网格划分, 得到结果如图 6 所示。将划分好网格的模型导人到 Flurnt 中。

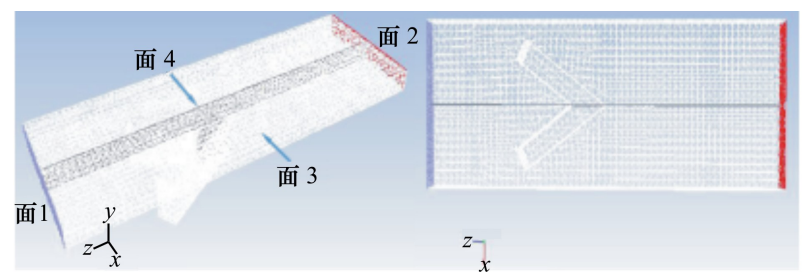

图 6 网格划分

\section{2 模型的边界条件}

模型假设: (1)由于是单一 $V$ 字型织构, 并且面 1 
相邻的 2 个侧面相互对称, 压强可以看做相等, 且其 不影响流动, 设为墙壁。(2)在 $\mathrm{V}$ 字型织构表面的油 膜被看做是一个完整的油膜, 没有破裂处。3油膜 受到的压力值为加载力与对磨件与试件的实际接触 面积的比值。

$$
p=\frac{F}{S}=\frac{50 \mathrm{~N}}{0.0000887 \mathrm{~m}^{2}}
$$

由 (2) 式知 $50 \mathrm{~N}$ 时输人压强应为 562429.7

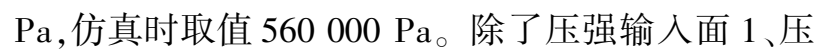
强输出面 2 , 其余面均为墙壁; 但面 3 设置为可移动 墙壁, 移动方向为由面 1 向面 2 , 以代表实验状态下 的对磨件的移动。移动速度

$$
v=\frac{r}{T}=\frac{0.006 \times 100 \mathrm{~m} / \mathrm{s}}{60}=0.01 \mathrm{~m} / \mathrm{s}
$$

由 (3) 式可知, 当转速为 $100 \mathrm{r} / \mathrm{min}$ 时, 对磨件 的平均线速度为 $0.01 \mathrm{~m} / \mathrm{s}$ 。

边界条件: 油密度 $\rho=895 \mathrm{~kg} / \mathrm{m}^{3}$, 润滑油动力黏 度 $\mu=0.055 \mathrm{~Pa} \cdot \mathrm{s}_{\text {。 }}$ 进油压强 (面 1 ) $p$ 分别为 $560000 \mathrm{~Pa}(50 \mathrm{~N}), 1120000 \mathrm{~Pa}(100 \mathrm{~N}), 1680000$ $\mathrm{Pa}(150 \mathrm{~N}), 2240000 \mathrm{~Pa}(200 \mathrm{~N})$, 出油压强(面 2) 为 $0 \mathrm{~Pa}_{\circ}$ 面 3 为移动壁面, 取平均线速度 $v=0.01$ $\mathrm{m} / \mathrm{s}$ 。压强均为相对压力 Gauge Pressure, 设置重力 方向为 $Y$ 轴负方向, 值为 $9.8 \mathrm{~m} / \mathrm{s}^{2}$, 采用 SIMPLE 算 法求解。

\section{3 仿真结果}

由于是在极小范围内取得单个 $\mathrm{V}$ 字型织构, 模 型设定的垂直方向即 $Y$ 轴方向压力值相同。仿真 结果所选用的面为整个模型的对称面, 即与面 1 和 面 2 正交且过模型中心的面 4。图 7 和图 8 分别为 4 种压力下的压强分布云图和湍流强度比较图。

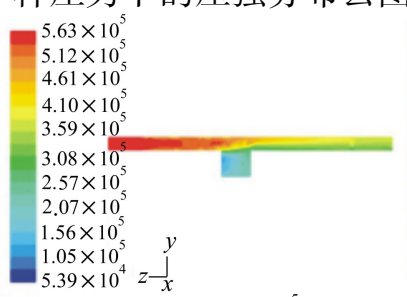

a) $5.6 \times 10^{5} \mathrm{~Pa}$

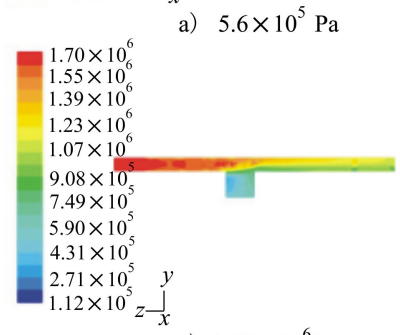

c) $1.68 \times 10^{6} \mathrm{~Pa}$

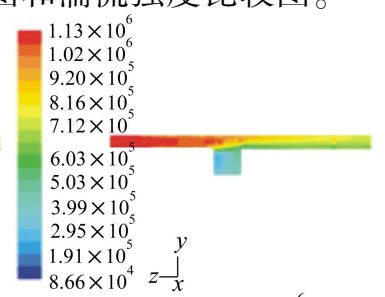

b) $1.12 \times 10^{6} \mathrm{~Pa}$

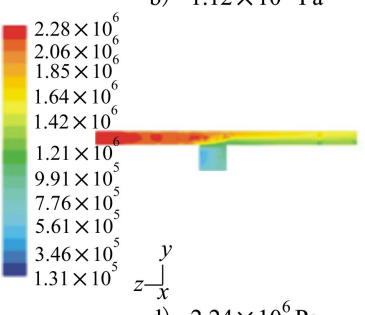

d) $2.24 \times 10^{6} \mathrm{~Pa}$
图 74 种压强下的压力分布云图

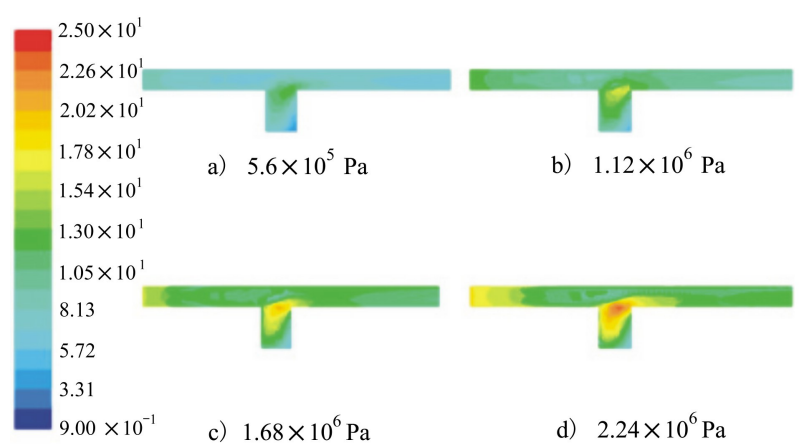

图 84 种压强下的湍流强度比较图

\section{4 仿真结果分析}

当润滑油流过织构存在区域时, $V$ 字型织构内 部的压强小, 润滑油流动表面的压强大。由于二者 存在压差, 润滑油会有从表面流向织构内部的趋势, 这样不利于润滑油保持其自身稳定性。但根据图 7 可以看出, 流体压强并没有在织构存在区域大幅度 下降,而是伴随着流体流经织构区域,高压区向上移 动, 与低压区形成了一个明显的斜线分界线。这就 表示织构不仅没有使得润滑油的压强骤降,还使其 高压区上移,减少了织构对流体压强的负影响,提高 了油膜稳定性。并且, 随着流体压强的增加, 织构的 影响范围更加广泛, 由图 7 可以看出压强越大, 高压 区域越远离织构,这样就最大限度地降低了织构附 近的压差, 间接增加了油膜的稳定性。通过图 8 可 以看出, 压强不同对湍流强度的影响是十分明显的。 在压强为 $560000 \mathrm{~Pa}$ 时, 湍流强度较大的地方为 $\mathrm{V}$ 字型织构内部以及出口部分, 其余部分湍流强度较 小。随着压强的增加, 湍流强度较大的区域逐渐由 $\mathrm{V}$ 字型织构内部曼延至织构表面。虽然湍流强度的 增大会提高摩擦力, 但是由于其增加了流动性, 也间 接提高了油膜的稳定性。油膜破裂对摩擦因数造成 的影响要远大于湍流强度对摩擦因数的影响。所 以,整体来说摩擦因数还是随着压强的增大而减 小的。

\section{3 结 论}

(1) V 字型表面织构可以在加载力及速度不断增 大的情况下,减小摩擦因数。(2)加载力与速度对摩 擦因数的影响呈近线性关系, 在一定误差范围内可 以通过二元线性方程表示, 且加载力对摩擦因数的 
影响能力更强。3 $\mathrm{V}$ 字型织构磨损的主要方式是气 蚀磨损, 它的主要区域是 $\mathrm{V}$ 字型表面织构的尖端部 分。(4) V 字型织构减小摩擦因数的原理与提高油膜 稳定性有着很大的关系。通过压强分布云图和湍流
强度云图都可以分析出在压强不断增加时油膜的速 度和流动轨迹, 湍流强度云图也证明了尖端部分的 磨损与流体运动规律的改变。

\section{参考文献:}

[1] 韩志武,任露泉, 刘祖斌. 激光织构仿生非光滑表面抗磨性能研究进展 [J]. 摩擦学学报, 2004, 24(4):289-293

HAN Zhiwu, REN Luquan, LIU Zubin. Investigation on Anti-Wear Ability of Bionic Nonsmooth Surfaces Made by Laser Textu$\operatorname{ring}[\mathrm{J}]$. Tribology, 2004, 24(4): 289-293 (in Chinese)

[2] 万轶, 熊党生. 激光表面织构化改善摩擦学性能的研究进展 $[\mathrm{J}]$. 摩擦学学报, 2006, 26( 6) : 603-607

WAN Yi, XIONG Dangsheng. Study of Laser Surface Texturing for Improving Tribological Properties [ J]. Tribology, 2006, 26 (6) : 603-607 (in Chinese)

[3] 历建全, 朱华. 表面织构及其对摩擦学性能的影响 [J]. 润滑与密封, 2009, 34(2): 94-97

LI Jianquan, ZHU Hua. Surface Texture and Its Influence on Tribological Properties [ J]. Lubrication Engineering, 2009, 34 (2) : 94-97 (in Chinese)

[4] ETSION I. Improving Tribological Performance of Mechanical Components by Laser Surface Texturing $[\mathrm{J}]$. Tribology Letters, $2004,17(4): 733-737$

[5] GUALTIERI E, BORGHi A, CALABRI L, et al. Increasing Nanohardness and Reducing Friction of Nitride Sreel by Laser Surface Texturing $[\mathrm{J}]$. Tribology International, 2009, 42(5): 699-705

[6] 王素华, 吴新跃. 基于摩擦学的表面织构技术应用研究进展 [J]. 工具技术, 2012, 45(12): 7-11

WANG Suhua, WU Xinyue. Research on Applications of Surface Texturing Based on Tribology [J]. Tool Engineering, 2012, 45 (12) : 7-11

[7] 王匀, 曾亚维, 陈立宇, 等. 表面织构在脂润滑条件下的摩擦性能研究 [J]. 润滑与密封, 2017, 42(4): 43-47

WANG Yun, ZENG Yawei, CHEN Liyu, et al. Study on Tribological Properties of Laser Textured Surface under Grease Lubrication $[\mathrm{J}]$. Lubrication Engineering, 2017, 42(4) : 43-47 (in Chinese)

[8] SAKA N, TIAN H, SUH N P. Boundary Lubrication of Undulated Metal Surfaces at Elevated Temperatures [J]. Tribology Transactions, 1989, 32(3) : 389-395

[9] TIAN H, SAKA N, SUH N P. Boundary Lubrication Studies on Undulated Titanium Surfaces[J]. Tribology Transactions, 1989, $32(3): 289-296$

[10] 郑晓辉, 宋皓, 张庆, 等. 激光表面织构化对材料摩擦学性能影响的研究进展 [J]. 材料导报, 2017, 31(9): 68-74 ZHENG Xiaohui, SONG Hao, ZHANG Qing, et al. Effect of Laser Surface Texturing on Tribological Properties of Materials: a Review $[\mathrm{J}]$. Materials Review, 2017, 31(9): 68-74 (in Chinese)

[11] NAKANo M, KOREnaga A, KOREnaga A, et al. Applying Micro-Texture to Cast Iron Surfaces to Reduce the Friction Coefficient under Lubricated Conditions [J]. Tribology Letters, 2007, 28: 131-137

[12] 王静秋, 王晓雷. 表面织构创新设计的研究回顾及展望 $[\mathrm{J}]$. 机械工程学报, 2015, 51(23): 84-95

WANG Jingqiu, WANG Xiaolei. State of the Art in Innovative Design of Surface Texture[J]. Journal of Mechanical Engineering, 2015, 51(23): 84-95 (in Chinese)

[13] 白少先, 柏林清, 孟祥凯, 等. 倾斜微孔密封端面气体润滑动压效应试验研究 [J]. 中国机械工程, 2013, 24 (6): $831-835$

BAI Shaoxian, BAI Linqing, MENG Xiangkai, et al. Experimental Research on Hydrodynamic Effect of Inclined Micro-Pored Gas Face Seals $[\mathrm{J}]$. China Mechanical Engineering, 2013, 24(6): 831-835 (in Chinese)

[14] YUAN Sihuan, HUANG Wei, WANG Xiaolei. Orientation Effects of Micro-Grooves on Sliding Surfaces[J]. Tribology International, 2011, 44(9) : 1047-1054

[15] 刘东雷, 孟小霞, 袁春俭, 等. 多种规则微造型表面摩擦特性的试验研究 [J]. 润滑与密封, 2008, 33: 28-31

LIU Donglei, MENG Xiaoxia, YUAN Chunjian, et al. Research on Tribological Performance of Texturing Surfaces[J]. Lubrica- 
tion and Engineering, 2008, 33: 28-31 (in Chinese)

[16] 宋保维, 袁潇, 胡海豹. 层流状态下超疏水表面流场建模与减阻特性仿真研究 $[\mathrm{J}]$. 西北工业大学学报, 2012, 30 (5): $712-717$

SONG Baowei, YUAN Xiao, HU Haibao. Simulating Flow Field of Superhydrophobic Surface in Laminar Flow to Reduce Its Drag [J]. Journal of Northwestern Polytechnical University, 2012, 30(5) : 712-717 (in Chinese)

[17] 马晨波, 朱华, 张文谦, 等. 往复条件下织构表面的摩擦学性能研究 $[\mathrm{J}]$. 摩擦学学报, 2011, 31(1): 50-55

MA Chenbo, ZHU Hua, ZHANG Wenqian, et al. Tribological Property of Textured Surface under Reciprocating Motion[J]. Tribology, 2011, 31(1): 50-55 (in Chinese)

[18] 丁行武, 王家序, 郭胤, 等. 基于滑动摩擦的摩擦副表面织构优化分析 $[\mathrm{J}]$. 四川大学学报, 2013, 45(增刊 1)：183-188 DING Hangwu, WANG Jiaxu, GUO Yin, et al. Optimization Analysis of the Surface Texture of Friction Pair Based on Sliding Friction [J]. Journal of Sichuan University, 2013, 45( suppl 1) : 183-188 (in Chinese)

\title{
Tribological Properties of V-Shaped Surface Texture under Oil Lubrication Condition
}

\author{
WU Yuanbo ${ }^{1}$, YANG Xuefeng ${ }^{1}$, WANG Shouren ${ }^{1}$, CHENG Jian ${ }^{2}$, \\ ZHANG Hui $^{1}$, LU Chongyang ${ }^{1}$, CHEN Hailong ${ }^{1}$ \\ $\left(\begin{array}{l}\text { 1.College of Mechanical Engineering, University of Jinan, Jinan 250022, China; } \\ \text { 2.College of Mechanical Engineering, Hubei University of Technology, Wuhan 430000, China }\end{array}\right)$
}

\begin{abstract}
In order to study the tribological properties of V-shaped texture under oil lubrication conditions, the loading force and speed are selected as the influencing factors, each factor selected six levels. Experimental study on friction and wear of $\mathrm{V}$-shaped texture with ring arrangement is finished by MMG-10 Multifunctional Friction and Wear Testing Machine, and the data of the experimental results are analyzed by using Matlab. The results show that there is a near linear relationship between the friction coefficient and the loading force and velocity. The relationship between the friction coefficient and the loading force and velocity can be expressed by a functional equation. The loading force has a greater influence on the friction coefficient than the speed. The SEM images of the post-test specimens show that the main weared zone of the $\mathrm{V}$-shaped texture is the tip part. Create a single V-shaped texture model with Solidworks and use CFD to divide the mesh into the Fluent solution. According to the pressure distribution cloud diagram and the turbulence intensity cloud diagram, the stability of the oil film is improved due to the enhanced fluidity of the oil film and the small change in the oil pressure. The tip portion is also the region with a large turbulence intensity value. The improvement of the stability of the oil film is the key to reduce the friction coefficient of the V-shaped texture when the loading force increases.
\end{abstract}

Keywords : V-shaped texture; friction and wear experiment; fluidity; oil lubrication 